\title{
EMERGING VIRAL DISEASES OF CYPRINIDS
}

Vladimir Radosavljevići ${ }^{*}$, Jelena Maksimović-Zorić ${ }^{1}$, Ljubiša Veljović ${ }^{1}$, Ksenija Nešić ${ }^{1}$, Zoran Marković ${ }^{2}$, Dragana Ljubojević Pelić ${ }^{3}$, Vesna Milićević ${ }^{1}$

${ }^{1}$ Scientific Institute of Veterinary Medicine of Serbia, Belgrade, Serbia

${ }^{2}$ University of Belgrade, Faculty of Agriculture, Belgrade, Serbia

${ }^{3}$ Scientific Veterinary Institute "Novi Sad", Novi Sad, Serbia

\begin{abstract}
The intensive aquaculture remains the world's fastest growing sector producing food of animal origin. In fact, it is the only animal food-producing sector growing faster than the human population, and provides an acceptable supplement to and substitute for wild fish. A number of cyprinid diseases have emerged globally and their study has become increasingly important. The expansion of aquaculture, which has relied heavily on the movement of animals and farming species new to aquaculture, has been paralleled with disease emergence. In the last few years several emerging or re-emerging fish diseases have been detected in cyprinid fish populations in Serbia. In this paper, the authors overview the major viral threats for cyprinid fishes in Serbia.
\end{abstract}

Keywords: cyprinids, fish viruses, emerging diseases

\footnotetext{
${ }^{1}$ Corresponding author: vladimiradosavljevic@yahoo.co.uk
} 


\section{NOVE I PRETEĆE VIRUSNE BOLESTI CIPRINIDA}

Vladimir Radosavljevićc ${ }^{*}$, Jelena Maksimović-Zorić1, Ljubiša Veljović1, Ksenija Nešić ${ }^{1}$, Zoran Marković ${ }^{2}$, Dragana Ljubojević Pelićn, ${ }^{3}$ Vesna Milićević ${ }^{1}$

${ }^{1}$ Naučni institut za veterinarstvo Srbije, Beograd, Srbija

${ }^{2}$ Poljoprivredni fakultet, Beograd, Srbija

${ }^{3}$ Naučni institut za veterinarstvo, Novi Sad, Srbija

\section{Kratak sadržaj}

Na svetskom nivou, intenzivna akvakultura je najbrže rastući sektor za proizvodnju hrane životinjskog porekla. Šta više, to je jedini sektor koji raste brže od ljudske populacije i obezbeđuje značajnu dopunu i zamenu izlovljavanju riba iz otvorenih voda. Na žalost ovaj trend je praćen pojavom brojnih bolesti ciprinida na globalnom nivou. Ekspanzija akvakulture, koja se u velikoj meri oslanja na trgovinu i promet riba, uključujući i vrste koje ranije nisu korišćenje u akvakulturi je dovela i do istovremenog širenja patogena. U poslednjih nekoliko godina u populaciji ciprinidnih riba $\mathrm{u}$ Srbiji otkriveno je nekoliko novih bolesti, a uočena je i ponovna pojava ranije prisutnih bolesti. $U$ ovom radu autori prezentuju najznačajnije nove i preteće bolesti ciprinida u Srbiji.

Ključne reči: ciprinidi, virusi riba, nove i preteće bolesti

\section{INTRODUCTION}

Diagnostic testing of cyprinids often results in the occurrence of the cytopathic effect on cell culture and virus isolation, but fortunately, they are mostly benign. For a long time, spring viremia of carp was single viral disease of cyprinids listed by the OIE. In 2007 koi herpesvirus disease (KHVD), caused by the Cyprinid herpesvirus 3 (CyHV-3), was listed by the World Organization of Animal Health (OIE) and listed as a non-exotic disease in the European Union, related to the Directive 2006/88/EC. Recently, concern has been shown about diseases caused by other viruses, primarily herpes and pox viruses. Goal of this paper is to present an overview of current viral threats for cyprinid fish in Serbia. 


\section{Carp Edema Virus (CEV)}

Although known for a long time as a cause of disease in koi carp in Japan, carp edema virus (CEV) has recently been recognized as a global threat to the koi and the common carp aquaculture. Carp Edema Virus (CEV) is the etiological agent of Carp edema virus disease (CEVD), firstly described in Japan in the 1970's as a viral edema of juvenile color Cyprinus carpio koi and later morphologically identified as a poxvirus. In koi, diseased fish exhibit erosive or hemorrhagic skin lesions with edema of the underlying tissues, thus the disease was originally named "viral edema of carp" (Oyamatsu et al., 1997). The disease has also been referred to as "koi sleepy disease" (KSD) because infected koi become lethargic and unresponsive (Miyazaki et al., 2005). After Japan, disease outbreaks in koi at import sites and in hobby ponds has been detected in USA since 1996.

In Europe, outbreaks of KSD and PCR detections of CEV-like virus were reported since 2009. In 2009 CEV first detection in Europe was in England in imported diseased koi. Low levels of CEV-like virus were also detected in healthy koi imports from Israel and Japan at ornamental fish wholesalers during 2013 in the UK (Way and Stone, 2013). In 2016, the disease outbreaks in koi are recorded in India and in China (Swaminathan et al., 2016; Zhang et al., 2017)

In koi carp, the virus causes severe damage to gill lamellae, leading to hypoxia and lethargy, which manifests as sleepy behaviour, and mortality can reach $80-100 \%$ (Ono et al., 1986; Lewisch and Gorgoglione et al., 2015).

In common carp, carp edema virus has been initially detected in the United Kingdom and in the Netherlands in 2012 (Way and Stone, 2013; Haenen et al., 2014). After those initial detections, the virus has been detected in Czech Republic and Poland in 2013 (Vesely et al., 2015; Matras et al, 2017), followed by Austria and Italy in 2014 (Lewisch et al., 2015; Pretto et al., 2015), and more recently in Hungary in 2016 (Adamek et al., 2018a). The virus has been detected in Lithuania and Croatia in 2018 (Adamek et al., 2018b).

In common carp, during outbreak of the disease, fish congregate lethargically under the water surface or lie at the bottom of the tank and die in the following 2 weeks. Gross changes with enophthalmos, gill hyperplasia, and anal ulcerative inflammation are evident in the infected fish (Jung-Schroers et al., 2015; Lewisch et al., 2015).

In Serbia, episodes of disease characterized by a typical sleepy behaviour, enophthalmia, generalized oedematous condition and gill necrosis, leading to hypoxia and mortality of up to $20 \%$ were observed during 2015 and 2016 
in spring time on many carp farms, but causative agent was detected in 2017 (Radosavljević et al., 2018). During April and May 2017 unusual mortalities occurred in common carp at water temperatures between $9^{\circ} \mathrm{C}$ and $15^{\circ} \mathrm{C}$. Diseased fish showed similar clinical signs and experienced about 20 percent mortality. Fish were lethargic, congregated around pond margins or at the water surface and became increasingly unresponsive.

\section{Herpesviral hematopoietic necrosis (HVHN)}

Cyprinid herpesvirus 2 (CyHV-2, Goldfish herpesvirus, GHV) is the causative agent of herpesviral haematopoietic necrosis (HVHN) in goldfish (Carassius auratus). The disease was first identified in Japan in 1992 and 1993 in goldfish (Carassius auratus) (Jung and Miyazaki, 1995). Until recently, Cyprinid herpesvirus 2 (CyHV-2, Goldfish herpesvirus, GHV) was described as the etiological agent of a disease named Herpesviral hematopoietic necrosis (HVHN), which occurred only in goldfish (Carassius auratus). This disease was first described in western Japan in the 1990s, causing high mortality in goldfish and occurring during the spring and autumn (Jung and Miyazaki, 1995). Since then, CyHV-2 has been reported in North America (Goodwin et al, 2006) as well as Taiwan (Chang et al, 1999) and Australia (Stephens et al., 2004). In Europe, the virus was first detected in the United Kingdom in 2006 (Philbey, 2006), followed by Switzerland in 2010 (Giovannini et al., 2015), Italy in 2013 (Fichi et al., 2013), France (Boitard et al., 2016) and Germany (Haenen et al., 2016). Clinically, affected goldfish display signs such as apathy, pale gills, increased respiratory rate, and ascites. Histopathological consistent finding in CyHV-2-infected goldfish is necrosis of the hematopoietic tissue in kidney and spleen. The disease in goldfish was not detected in Serbia, but outbreak of a disease caused with CyHV-2 was recorded in Prussian carp (Carassius gibelio) in 2017.

Recently, the virus has been detected in Prussian carp (C. gibelio) in China (Wang et al., 2012), and also in Czech Republic (Daněk et al., 2012), the Netherlands (Haenen et al., 2016) and in Serbia (Radosavljević et al., 2018). In Serbia, the outbreak of herpesviral hematopoietic necrosis in Prussian carp lasted for 1 week, at a water temperature of $26^{\circ} \mathrm{C}$, and did not affect other fish species. Some fish showed a whitish slime layer over their eyes and an erythema of their skin, sometimes with haemorrhagic scales. Since the reports suggest that this virus has been spreading, and also CyHV-2 has the potential to infect other species of the genus Carassius as a host, understanding the properties and the preventive measures of this disease has become important. 


\section{CONCLUSIONS}

Understanding of the emerging cyprinid viruses is still evolving. It is very probable that more cyprinid viruses will be detected as improved diagnostic methods come into general use. However, for detection of different emerging viruses of cyprinids, advanced diagnostic techniques have had to be used. The present findings indicate that the prevalence and spread of CEV and HVHN must be closely monitored in our country to avoid potential economic losses.

\section{ACKNOWLEDGEMENT}

This study was financially supported by a grant from the Ministry of Education, Science and Technology Development of the Republic of Serbia, under the projects TR31075 and TR31011.

\section{REFERENCES}

1. Adamek M., Baska F., Vincze B., Steinhagen D.: Carp edema virus from three genogroups is present in common carp in Hungary. Journal of fish diseases. 41, 3, 463-468, 2018a.

2. Adamek M., Baska F., Nienius D., Radosavljevic V., Zrnčić S., Brnić D., Oraić D., Steinhagen D.: Erste Nachweise des carp edema virus in Ungarn, Litauen, Kroatien und Serbien bestätigen eine sehr weite Verbreitung des Virus in Karpfenbeständen in Europa. XVII Gemeinschaftstagung der deutschsprachigen Sektionen der EAFP zum Thema Fischkrankheiten, 3-5. october, Fribourg/Schweiz, P-10, 2018 b.

3. Boitard PM., Baud M., Labrut S., de Boisseson C., Jamin M., Bigarré L.: First detection of Cyprinid Herpesvirus $2(\mathrm{CyHV}-2)$ in goldfish (Carassius auratus) in France. Journal of fish diseases, 39, 6, 673-680, 2016.

4. Chang P., Lee S., Chiang H.: Epizootic of Herpes-like virus infection in goldfish, Carassius auratus in Taiwan. Fish Pathology, 34, 209-210, 1999.

5. Daněk T., Kalous L., Vesel T., Krásová E., Reschová S., Rylková K., Kulich P., Petrty ML., Pokorová D., Knytl M.: Massive mortality of Prussian carp Carassius gibelio in the upper Elbe basin associated with herpesviral hematopoietic necrosis (CyHV-2). Diseases of aquatic organisms, 102, 2, 87-95, 2012.

6. Fichi G., Cardeti G., Cocumelli C.: Detection of Cyprinid herpesvirus 2 in association with an Aeromonas sobria infection of Carassius carassius (L.) in Italy. Journal of fish diseases, 36, 10, 823-830, 2013.

7. Giovannini S., Bergmann SM., Keeling C., Lany C., Schütze H., Schmidt- 
Posthaus H.: Herpesviral Hematopoietic Necrosis in Goldfish in Switzerland: Early Lesions in Clinically Normal Goldfish (Carassius auratus). Veterinary Pathology, 53, 4, 847-852, 2015.

8. Goodwin AE., Khoo L., LaPatra SE.: Goldfish hematopoietic necrosis herpesvirus (Cyprinid herpesvirus 2) in the USA: Molecular confirmation of isolates from diseased fish. Journal of Aquatic Animal Health, 18, 11-18, 2006.

9. Haenen O., Way K., Stone D., Engelsma M.: Koi sleepy disease found for the first time in koi carps in the Netherlands. Tijdschr Diergeneeskd, 139, 26-29, 2014.

10. Haenen O., Way K., Gorgoglione B., Ito T., Paley R., Bigarré L., Walcek T.: Novel viral infections threatening Cyprinid fish. Bulletin-European Association of Fish Pathologists, 36, 1, 11, 2016.

11. Jung S.J., Miyazaki T.C.: Herpesviral haematopoietic necrosis of goldfish, Carassius auratus (L.). Journal of fish diseases, 18, 211-220, 1995.

12. Jung-Schroers V., Adamek M., Teitge F., Hellmann JO.: Another potential carp killer? Carp edema virus disease in Germany. BMC Veterinary Research, 11, 114. 2015.

13. Lewisch E,. Gorgoglione B., Way K., El-Matbouli M.: Carp edema virus/ koi sleepy disease: an emerging disease in Central-East Europe. Transboundary Emerging Diseases, 62, 6-12, 2015.

14. Matras M., Borzym E., Stone D., Way K.: Carp edema virus in Polish aquaculture - evidence of significant sequence divergence and a new lineage in common carp Cyprinus carpio (L.). Journal of fish diseases, 40, 319-325, 2017.

15. Miyazaki T., Isshiki T., Katsuyuki H.: Histopathological and electron microscopy studies on sleepy disease of koi Cyprinus carpio koi in Japan. Diseases of aquatic organisms, 65, 197-207, 2005.

16. Ono S., Nagai A., Sugai N.: A histopathological study on juvenile color carp, Cyprinus carpio, showing edema. Fish Pathology, 21, 167-175, 1986.

17. Oyamatsu T., Hata N., Yamada K., Sano T., Fukuda H.: An etiological study on mass mortality of cultured color carp juveniles showing edemas. Fish Pathology, 32, 81-88, 1997.

18. Philbey A.W.: Herpesvirus haematopoietic necrosis in a goldfish (Carassius auratus) in the UK. Veterinary Record, 158, 800-801, 2006.

19. Pretto T., Abbadi M., Panzarin V., Quartesan R., Manfrin A., Toffan A.: Carp edema virus (CEV): first detection in Italy. EAFP 17th International Conference on disease of fish and shellfish, 7-11. September, Las Palmas de Gran Canaria, European Association of Fish Pathologists, 2015, P-119, 343.

20. Radosavljević V., Adamek M., Milićević V., Maksimovic-Zorić J., Steinhagen D.: Occurrence of two novel viral pathogens (CEV and CyHV-2) 
affecting Serbian cyprinid aquaculture and ichthyofauna. Journal of fish diseases, 41, 5, 851-854. 2018.

21. Stephens FJ., Raidal SR., Jones B.: Haematopoietic necrosis in a goldfish (Carassius auratus) associated with an agent morphologically similar to herpesvirus. Australian Veterinary Journal, 82, 167-169. 2004.

22. Swaminathan TR., Kumar R., Dharmaratnam A., Basheer VS., Sood N., Pradhan PK., Sanil NK., Vijayagopal P., Jena JK.: Emergence of carp edema virus in cultured ornamental koi carp, Cyprinus carpio koi, in India. Journal of General Virology, 16, 97, 12, 3392-3399, 2016.

23. Vesely T., Pokorova D., Reschova S., Piacková V.: Detection of carp edema virus in common carp (Cyprinus carpio) and koi carp in the Czech Republic. EAFP 17th International Conference on disease of fish and shellfish, 7-11. September, Las Palmas de Gran Canaria, European Association of Fish Pathologists, 2015, P-122, 346.

24. Way K., Stone D.: Emergence of carp edema virus-like (CEV-like) disease in the UK. Finfish News, 15, 32-34. 2013.

25. Wang L., He J., Liang L., Zheng X., Jia P., Shi X., Lan W., Xie J., Liu H., Xu P.: Mass mortality caused by Cyprinid Herpesvirus 2 (CyHV-2) in Prussian carp (Carassius gibelio) in China. Bulletin-European Association of Fish Pathologists, 32, 5, 164-173, 2012.

26. Zhang X., Ni Y., Ye J., Xu H., Hou Y., Luo W., Shen W.: Carp edema virus, an emerging threat to the carp (Cyprinus carpio) industry in China. Aquaculture, 474, 34-39. 2017.

Primljeno: 31.07.2018.

Odobreno: 28.10.2018. 